Journal of Aquaculture and Fish Health Vol. 3 No.1

\title{
PEMBERIAN BEBERAPA DOSIS ENZIM PADA PAKAN KOMERSIAL TERHADAP KANDUNGAN SERAT KASAR, BAHAN ORGANIK DAN BETN
}

\author{
Effect of given few doses enzyme to the crude fibre, organic matter, and nitrogen free \\ extract in commercial fish food
}

\author{
Pramono Kusuma Wardani ${ }^{* 1}$, Muhammad Arief ${ }^{2}$ dan Muhammad Anam Al-Arif ${ }^{3}$ \\ ${ }^{1}$ Program Studi Budidaya Perairan, Fakultas Perikanan dan Kelautan, Universitas Airlangga, Surabaya \\ ${ }^{2}$ Departemen Manajemen Kesehatan Ikan dan Budidaya Perairan, Fakultas Perikanan dan Kelautan, Universitas \\ Airlangga, Surabaya \\ ${ }^{3}$ Departemen Peternakan, Fakultas Kedokteran Hewan, Universitas Airlangga, Surabaya \\ *pramono@fpk.unair.ac.id
}

\begin{abstract}
Abstrak
Manajemen pakan merupakan salah satu unsur yang sangat menunjang suatu kegiatan usaha budidaya perikanan, sehingga pakan yang tersedia harus memadai dan memenuhi kebutuhan ikan tersebut. Ketersediaan pakan ikan yang efektif, efisien, ramah lingkungan, dan dengan harga yang terjangkau perlu diperhatikan. Nutrisi dalam pakan sangat penting karena beberapa nutrisi tersebut merupakan sumber energi bagi ikan. Nutrisi pakan dalam ransum hendaknya tersedia dalam jumlah yang cukup dan seimbang sebab keseimbangan bahan pakan dalam ransum sangat berpengaruh terhadap daya cerna. Enzim bekerja secara spesifik pada substrat yang kebanyakan terdapat di dalam bahan pakan baik berupa serat kasar yang merupakan bentuk molekul besar sehingga nantinya dapat diserap dan digunakan langsung. Enzim yang ditambahkan sebagai suplemen pada pakan untuk memecah faktor anti nutrisi yang terdapat di dalam campuran pakan, kebanyakan dari senyawa tersebut tidak mudah dicerna oleh enzim endogeneous di dalam ikan dan dapat mengganggu pencernaan normal. Penelitian ini bertujuan untuk memberikan informasi pada masyarakat, mahasiswa, dan pembudidaya ikan pada khususnya mengenai pengaruh pemberian beberapa dosis enzim pada pakan komersial terhadap kandungan serat kasar, bahan organik, dan BETN, sehingga bermanfaat bagi semua pihak khususnya terhadap bidang perikanan. Penelitian ini menggunakan Rancangan Acak Lengkap (RAL) dengan empat perlakuan dan lima ulangan. Perlakuan yang digunakan adalah kontrol (P0), pemberian Enzim 2,5\% (P1), pemberian Enzim 5\% (P2) dan pemberian Enzim $7,5 \%$ (P3) dengan masing-masing ulangan lima kali. Parameter yang diamati adalah kandungan serat kasar, bahan organik dan BETN setelah fermentasi selama 5 jam. Data tentang kandungan serat kasar, bahan organik dan BETN yang diperoleh dari penelitian ini dianalisis menggunakan Uji F metode Rancangan Acak Lengkap (RAL) jika terdapat perbedaan yang nyata maka dilanjutkan dengan uji Jarak Berganda Duncan (Duncan's Multiple Range Test). Hasil penelitian ini menunjukkan bahwa pemberian enzim pada pakan komersial dapat menurunkan kandungan serat kasar dari sebesar 10,6487\% (P0) menjadi sebesar 8,7038\% (P1), dapat menurunkan kandungan BETN dari sebesar 34,4230\% (P0) menjadi sebesar 34,1849\% (P1), dan pada kandungan bahan organik tidak berpengaruh. Perlu dilakukan penelitian lebih lanjut pada dosis enzim $2,5 \%$ terhadap ikan uji serta dilakukan penelitian lebih lanjut dengan lama inkubasi yang berbeda pada perlakuan $>5$ jam untuk mengetahui pengaruh lama inkubasi enzim pada pakan komersial terhadap kandungan serat kasar, BETN dan bahan organik.
\end{abstract}

Kata kunci: Bahan organik, BETN

\section{Abstract}

Feed management is one of the elements that strongly supports an aquaculture business, so that the available feed must be adequate and meet the needs of these fish. Availability of fish food that is effective, efficient, environmentally friendly, and at an affordable price needs attention. Nutrition in feed is very important because some of these nutrients are a source of energy for fish. Feed nutrition in the ration should be available in sufficient and balanced quantities because the balance of feed ingredients in the ration is very influential on digestibility. Enzymes work specifically on the substrate which is mostly contained in good feed ingredients in the form of crude fiber which is a form of large molecules so that later can be absorbed and used directly. An enzyme that is added as a supplement to the feed to break down the anti-nutritional factors contained in the feed mixture, most of which are not easily digested by endogeneous enzymes in fish and can interfere with normal digestion. This study aims to provide information to the public, students and fish farmers in particular regarding the effect of giving several doses of enzymes to commercial feed on the content of crude fiber, organic matter, 
and BETN, so that it is beneficial for all parties, especially in the fisheries sector. This study used a completely randomized design (CRD) with four treatments and five replications. The treatments used were control (P0), $2.5 \%$ Enzyme (P1), 5\% Enzyme (P2) and 7.5\% Enzyme (P3) with each replication five times. The parameters observed were crude fiber content, organic matter and BETN after 5 hours of fermentation. Data on crude fiber content, organic matter and BETN obtained from this study were analyzed using the F-Test Complete Random Design (CRD) method if there were significant differences then continued with Duncan's Multiple Range Test. The results of this study indicate that the administration of enzymes in commercial feed can reduce the crude fiber content of $10.6487 \%$ (P0) to $8.7038 \%$ (P1), which can reduce the BETN content from $34.4230 \%$ (P0) to $34,1849 \%$ (P1), and the organic matter content has no effect. Further research is needed at the $2.5 \%$ enzyme dose of the test fish and further research with different incubation periods at the treatment $>5$ hours to determine the effect of enzyme incubation time on commercial feed on crude fiber content, BETN and organic matter.

Keywords: Organic matter, NFE

\section{PENDAHULUAN}

Manajemen pakan merupakan salah satu unsur yang sangat menunjang suatu kegiatan usaha budidaya perikanan, sehingga pakan yang tersedia harus memadai dan memenuhi kebutuhan ikan. Kegiatan budidaya ikan, $60-70 \%$ biaya produksi digunakan untuk biaya pakan (Afrianto dan Liviawaty, 2005).

Menurut Cahyono (2001), pakan yang baik harus memiliki nutrisi yang lengkap yaitu protein, lemak, karbohidrat, vitamin dan mineral. Nutrisi dalam pakan sangat penting karena beberapa nutrisi tersebut merupakan sumber energi bagi ikan. Nutrisi pakan dalam ransum hendaknya tersedia dalam jumlah yang cukup dan seimbang sebab keseimbangan bahan pakan dalam ransum sangat berpengaruh terhadap daya cerna (Tillman dkk, 1991).

Fraksi-fraksi yang hilang dalam proses pembakaran adalah bahan organik yang dikandung bahan pakan tersebut. Abu sisa pembakaran dianggap sebagai mineral bahan makanan. Selisih antara bahan kering dengan mineral adalah bahan organik (Amrullah, 2003).

Bahan Ekstrak Tanpa Nitrogen (BETN) dalam pakan merupakan salah satu bagian dari karbohidrat. Kandungan BETN suatu bahan pakan sangat tergantung pada komponen lainnya, seperti abu, protein kasar, serat kasar dan lemak kasar. Hal ini disebabkan penentuan kandungan BETN hanya berdasarkan perhitungan dari zat-zat yang tersedia (Suparjo, 2010).

Kebanyakan ikan dapat mentoleransi kandungan serat kasar hingga 8\% pada pertumbuhannya, tetapi kandungan serat kasar yang lebih tinggi dari $8 \%$ dapat menekan pertumbuhan (NRC, 1993). Salah satu alternatif yang dapat dilakukan untuk menurunkan kandungan serat kasar pada pakan adalah dengan cara suplementasi enzim pada pakan.

Enzim adalah biokatalisator organik yang dihasilkan organisme hidup di dalam protoplasma, yang terdiri atas protein atau suatu senyawa yang berikatan dengan protein (Mustahib, 2011). Suatu enzim dapat mempercepat suatu proses reaksi hingga $10^{8}$ sampai $10^{11}$ kali lebih cepat daripada tanpa katalis (Poedjiadi, 1994).

Enzim selulase adalah enzim terinduksi yang disintesis mikroorganisme selama ditumbuhkan dalam medium selulosa (Lee and Koo, 2001). Suplementasi enzim selulase bertujuan untuk mendegradasi molekul komplek seperti selulosa menjadi karbohidrat yang lebih sederhana seperti glukosa, sebelum diberikan pada ikan. Enzim amilase dapat memecah ikatan-ikatan pada amilum hingga terbentuk maltosa (Poedjiadi dan Supriyanti, 2009). Enzim yang digunakan pada penelitian ini adalah enzim kompleks yang di dalamnya terdapat enzim selulase dan amilase.

\section{METODOLOGI Waktu dan Tempat}

Penelitian dilaksanakan di Laboratorium Makanan Ternak Fakultas Kedokteran Hewan Universitas Airlangga pada tanggal 08 - 12 November 2013. 


\section{Materi Penelitian}

Peralatan yang digunakan dalam penelitian ini meliputi: gelas ukur, spray, spuit (alat suntik), timbangan digital, sendok, baki, kantong plastik, kertas label dan karet.

Bahan yang digunakan dalam penelitian ini terdiri dari enzim dan pakan komersial atau pakan yg dijual dipasaran. Enzim dalam penelitian ini adalah enzipro yang mengandung 12 macam enzim yaitu enzim protease, enzim lipase, enzim amilase, enzim glukanase, enzim xilanase, enzim selulase, enzim pektinase, enzim fitase, enzim kitinase, enzim alinase, enzim L-asparaginase, enzim katalase yang diperoleh dari CV. M. Pakan komersial dalam penelitian ini adalah pakan produk MS. Bahan penunjang lain yang digunakan dalam proses fermentasi ini yaitu akuades steril.

\section{Metode Penelitian}

Rancangan Penelitian

Metode penelitian ini bersifat eksperimental. Penelitian ini menggunakan Rancangan Acak Lengkap (RAL) dengan empat perlakuan dan lima ulangan. Menurut Kusriningrum (2008), rumus yang digunakan untuk menentukan ulangan yang diberikan adalah:

$$
\mathrm{t}(\mathrm{n}-1) \geq 15
$$

Keterangan :

$\mathrm{t}=$ total perlakuan $; \mathrm{n}=$ jumlah ulangan

Perlakuan pada penelitian ini adalah sebagai berikut :

P0 : Pakan 200 gram + Enzim $0 \mathrm{ml}$

P1 : Pakan 200 gram + Enzim 0,5 ml

P2 : Pakan 200 gram + Enzim $1 \mathrm{ml}$

P3 : Pakan 200 gram + Enzim 1,5 ml

\section{Prosedur Kerja}

Pakan komersial ditimbang sebanyak 200 gram untuk masing-masing perlakuan. Enzim disiapkan dengan dosis $0 \mathrm{ml}, 0,5 \mathrm{ml}$, $1 \mathrm{ml}$ dan $1,5 \mathrm{ml}$ menggunakan spuit (alat suntik) ukuran $10 \mathrm{ml}$. Enzim diletakkan pada botol spray dan kemudian dicampur dengan akuades sebesar 5\% dari pakan sampai merata. Pakan komersial diletakkan dalam suatu wadah dan kemudian enzim yang sudah tercampur akuades disemprotkan hingga merata.

Pakan yang telah dicampur dengan enzim tersebut dimasukkan dalam kantong plastik dan kantong plastik tersebut diikat menggunakan karet gelang untuk kemudian diinkubasi selama 5 jam dalam keadaan anaerob. Pakan tersebut dianalisis untuk mengetahui kandungan serat kasar dan pakan dihitung untuk mengetahui bahan organik dan BETN.

\section{Variabel Penelitian}

Pada penelitian ini terdapat 3 variabel antara lain:

1) Variabel bebas dalam penelitian ini adalah pemberian dosis $0 \mathrm{ml}, 0,5 \mathrm{ml}, 1 \mathrm{ml}$ dan $1,5 \mathrm{ml}$.

2) Variabel kendali, dalam penelitian ini adalah pakan komersial dan enzim komersial.

3) Variabel tergantung, dalam penelitian ini adalah kandungan pada serat kasar, bahan organik dan BETN.

\section{Analisis Data}

Data yang diperoleh dianalisis menggunakan Uji $\mathrm{F}$ metode Rancangan Acak Lengkap (RAL) jika terdapat perbedaan yang nyata maka dilanjutkan dengan uji Jarak Berganda Duncan (Duncan's Multiple Range Test) ) dengan taraf nyata $\alpha$ $=0,05$ atau tingkat kepercayaan $95 \%$ (Kusriningrum, 2008).

\section{HASIL DAN PEMBAHASAN Serat Kasar}

Rata-rata kandungan bahan organik yang telah difermentasi dengan enzim dapat dilihat pada Tabel 1. 
Tabel 1. Rata-rata kandungan serat kasar berdasarkan bahan kering $100 \%$ pada pakan komersial yang difermentasi dengan enzim komersial

\begin{tabular}{|c|c|c|}
\hline Perlakuan & Rata-Rata $(\mathbf{x} \pm$ SD) & $\begin{array}{c}\text { Transformasi }(\sqrt{ }) \\
\mathbf{x} \pm \text { SD }\end{array}$ \\
\hline P0 & $10,6487 \pm 0,2134$ & $3,2631^{\mathrm{a}} \pm 0,0327$ \\
\hline P1 & $8,7038 \pm 0,4788$ & $2,9493^{\mathrm{c}} \pm 0,0826$ \\
\hline P2 & $9,223 \pm 0,637$ & $3,0355^{\mathrm{bc}} \pm 0,1058$ \\
\hline P3 & $9,7739 \pm 0,4014$ & $3,1258^{\mathrm{b}} \pm 0,0644$ \\
\hline
\end{tabular}

Keterangan:

a,b : Superkrip yang berbeda pada kolom menunjukkan perbedaan yang nyata $(\mathrm{P}<0,05)$

Hasil analisis varian diperoleh perbedaan yang nyata terhadap kandungan serat kasar $(\mathrm{P}<0,05)$. Pada perlakuan tersebut selanjutnya dilakukan Uji Jarak Berganda Duncan (Duncan's Multiple Range Test) diperoleh bahwa kandungan serat kasar pada P0 yang merupakan kontrol dari setiap perlakuan berbeda nyata dengan $\mathrm{P} 1, \mathrm{P} 2$ dan P3.

Kandungan serat yang rendah terdapat pada perlakuan P1 yang tidak berbeda nyata dengan $\mathrm{P} 2$ sedangkan berbeda nyata dengan P0 dan P3. Kandungan serat kasar pada perlakuan P2 tidak berbeda nyata dengan perlakuan P1 dan P3. Kandungan serat kasar tersebut berturut-turut adalah pada perlakuan P0 sebesar 10,6487\%, perlakuan P1 sebesar 8,7038\%, perlakuan P2 sebesar 9,223\% dan perlakuan P3 sebesar 9,7739\%.

Menurut Nainggolan dan Adimunca (2005) serat kasar adalah serat tumbuhan yang tidak larut dalam air yang terdiri dari tiga macam yaitu selulosa, hemiselulosa dan lignin. Serat kasar merupakan bagian dari karbohidrat dan didefinisikan sebagai fraksi yang tersisa setelah dicerna dengan larutan asam sulfat standar dan sodium hidroksida pada kondisi terkontrol (Suparjo, 2010).

Pada Tabel 1 dapat dilihat bahwa P1 dengan penambahan enzim 2,5\% memberikan hasil penurunan kandungan serat kasar yang baik menjadi 8,7038\% namun tidak berbeda nyata dengan perlakuan P2 menjadi
9,223\%. Pada perlakuan P1 dikatakan hasil penurunan serat kasar yang baik karena sesuai dengan pendapat NRC (1993). Kebanyakan ikan dapat mentoleransi kandungan serat kasar hingga $8 \%$ pada pertumbuhannya, tetapi kandungan serat kasar yang lebih tinggi dari 8\% dapat menekan per-tumbuhan. Pemberian serat kasar dalam jumlah yang besar dapat menyebabkan gangguan pada proses metabolisme tubuh (Afrianto dan Liviawati, 2005).

Penurunan kandungan serat kasar dikarenakan enzim komersial pada penelitian ini terdapat enzim selulase yang akan mengubah serat kasar (selulosa) menjadi molekul yang lebih sederhana sehingga tidak lagi sebagai polisakarida. Hal ini sependapat dengan Ikram dkk (2005) bahwa enzim selulase termasuk sistem multienzim yang terdiri dari tiga komponen yaitu endoglukanase, yang mengurai polimer selulosa untuk menghasilkan oligodekstrin dengan panjang rantai yang bervariasi, eksoglukanase yang mengurai serat kasar (selulosa) dari ujung pereduksi dan non-pereduksi untuk menghasilkan selulosa ikatan pendek atau selobiosa, dan $\beta$-glukosidase yang mengurai selobiosa untuk menghasilkan glukosa.

\section{BETN}

Rata-rata kandungan BETN pakan komersial yang telah difermentasi dengan enzim komersial dapat dilihat pada Tabel 2. 
Tabel 2. Rata-rata kandungan BETN berda-sarkan bahan kering 100\% pakan komersial yang difermentasi dengan enzim komersial

\begin{tabular}{|c|c|}
\hline Perlakuan & Rata-Ratā $(\mathbf{x} \pm$ SD) \\
\hline P0 & $34,4230^{\mathrm{a}} \pm 0,7317$ \\
\hline P1 & $34,1849^{\mathrm{a}} \pm 0,7989$ \\
\hline P2 & $32,0475^{\mathrm{b}} \pm 0,9283$ \\
\hline P3 & $32,9908^{\mathrm{ab}} \pm 1,466$ \\
\hline
\end{tabular}

Keterangan:

a,b : Superkrip yang berbeda pada kolom menunjukkan perbedaan yang nyata $(\mathrm{P}<0,05)$

Hasil analisis varian memperoleh perbedaan yang nyata terhadap kandungan BETN pada pakan komersial $(\mathrm{P}<0,05)$. Pada perlakuan tersebut selanjutnya dilakukan Uji Jarak Berganda Duncan (Duncan's Multiple Range Test) diperoleh bahwa kandungan BETN tanpa pemberian enzim komersial yaitu P0 tidak berbeda nyata dengan pemberian enzim komersial $2,5 \%$ yaitu $\mathrm{P} 1$ dan pemberian enzim komersial $7,5 \%$ yaitu P3. Perlakuan yang baik dalam penelitian ini adalah pada perlakuan dengan pemberian enzim 2,5\% yaitu P1. Kandungan BETN tersebut berturut-turut adalah P0 sebesar 34,4230\%, P1 sebesar 34,1849\%, P2 sebesar $32,0475 \%$ dan P3 sebesar 32,9908\%.

Kandungan BETN suatu bahan pakan sangat tergantung pada komponen lainnya, seperti abu, protein kasar, serat kasar dan lemak kasar. BETN merupakan karbohidrat yang dapat larut meliputi monosakarida, disakarida dan polisakarida yang mudah larut dalam larutan asam dan basa serta memiliki daya cerna yang tinggi (Anggorodi, 1994).

Berdasarkan hasil penelitian pemberian beberapa dosis enzim komersial pada pakan komersial yang dilihat pada Tabel 2 dan hasil Analisis Varian menunjukkan bahwa pemberian enzim komersial terdapat perbedaan yang sangat nyata terhadap kandungan BETN pada pakan komersial. Pada Tabel 2 dapat dilihat bahwa P1 dengan dosis enzim 2,5\% memberikan hasil kandungan BETN yang baik sebesar $34,1849 \%$, akan tetapi tidak terdapat perbedaan nyata dengan P3 dan P0 dimana P0 merupakan kontrol dari setiap perlakuan yang memberikan hasil kandungan BETN sebesar 34,4230\% (P0) dan 32,9908\% (P3).

Penurunan BETN pada penelitian ini karena enzim yang terkandung bukan hanya enzim selulase tetapi terdapat juga enzim amilase, jika hanya enzim selulase maka kemung-kinan kandungan BETN akan naik tetapi jika BETN turun kemungkinan pemecahan serat kasar oleh enzim selulase tidak sampai menjadi monosakarida jadi tidak ada penam-bahan kandungan BETN. Enzim amilase memecah kandungan BETN menjadi bentuk lain yang sesuai dengan pernyataan Poedjiadi dan Supriyanti (2009) bahwa enzim amilase memecah ikatan-ikatan pada amilum hingga terbentuk maltosa.

\section{Bahan Organik}

Rata-rata kandungan bahan organik yang telah difermentasi dengan enzim dapat dilihat pada Tabel 3 .

Tabel 3. Rata-rata kandungan bahan organik berdasarkan bahan kering $100 \%$ pada pakan komersial yang difermentasi dengan enzim komersial

\begin{tabular}{|c|c|c|}
\hline Perlakuan & Rata-Rata $(\mathbf{x} \pm$ SD) & $\begin{array}{c}\text { Transformasi }(\sqrt{ }) \\
\mathbf{x} \pm \text { SD }\end{array}$ \\
\hline P0 & $89,825 \pm 0,0566$ & $9,4776 \pm 0,003$ \\
\hline P1 & $89,4766 \pm 0,4063$ & $9,4592 \pm 0,0215$ \\
\hline P2 & $89,5764 \pm 0,0918$ & $9,4645 \pm 0,0048$ \\
\hline P3 & $89,6424 \pm 0,1314$ & $9,468 \pm 0,0069$ \\
\hline
\end{tabular}

Keterangan : Perlakuan tidak menunjukkan perbedaan $(\mathrm{P}>0,05)$ 
Hasil rata-rata kandungan bahan organik dari ke empat perlakuan diketahui P0 memiliki kandungan rata-rata bahan organik tertinggi dimana P0 merupakan kontrol dari setiap perlakuan, sedangkan rata-rata kandungan bahan organik yang rendah terdapat pada perlakuan P1 dengan penambahan enzim komersial 2,5\%. Dari hasil analisis varian diperoleh tidak adanya perbedaan terhadap kandungan bahan organik $(\mathrm{P}>0,05)$.

Fraksi-fraksi yang hilang dalam proses pembakaran adalah bahan organik yang dikandung bahan pakan tersebut. Abu sisa pembakaran dianggap sebagai mineral bahan makanan. Selisih antara bahan kering dengan mineral adalah bahan organik (Amrullah, 2003).

Berdasarkan hasil penelitian pemberian beberapa dosis enzim komersial pada pakan komersial yang dapat dilihat pada Tabel 4 dan hasil Analisis Varian menunjukkan bahwa pemberian enzim komersial menunjukkan tidak ada perbedaan yang nyata terhadap kandungan bahan organik pada pakan komersial, hal ini dikarenakan kandungan bahan organik suatu bahan pakan tergantung pada komponen lainnya seperti bahan kering dan abu (Amrullah, 2003).

Abu atau bahan anorganik tidak banyak dipengaruhi oleh proses fermentasi, sehingga kandungan bahan organik juga tidak berpengaruh. Menurut pendapat Tilman dkk (1991) bahwa kandungan bahan organik mencerminkan kandungan protein kasar, lemak kasar, serat kasar dan BETN. Pada penelitian ini kandungan protein meningkat namun kandungan bahan lainnya (serat kasar, lemak kasar dan BETN) menurun, sehingga pada akhirnya tidak ada perbedaan yang nyata pada bahan organik.

\section{KESIMPULAN DAN SARAN Kesimpulan}

Berdasarkan hasil yang diperoleh pada penelitian pemberian beberapa dosis enzim komersial pada pakan komersial, maka dapat ditarik kesimpulan sebagai berikut: pemberian enzim pada pakan komersial dapat menurunkan kandungan serat kasar dari sebesar $10,6487 \%$ (P0) menjadi sebesar 8,7038\% (P1).

Selain itu, pemberian enzim pada pakan komersial dapat menurunkan kandungan BETN dari sebesar 34,4230\% (P0) menjadi sebesar 34,1849\% (P1). Namun, pemberian enzim pada pakan komersial tidak berpengaruh terhadap kandungan bahan organik.

\section{Saran}

Berdasarkan hasil penelitian yang telah dilakukan dapat disarankan dosis enzim 2,5\% dilakukan aplikasi terhadap ikan uji. Selanjutnya dapat dilakukan penelitian lebih lanjut dengan lama inkubasi yang berbeda pada perlakuan $>5$ jam untuk mengetahui pengaruh lama inkubasi enzim pada pakan komersial terhadap kandungan serat kasar, BETN dan bahan organik.

\section{DAFTAR PUSTAKA}

Afrianto, E dan E. Liviawati. 2005. Pakan Ikan. Kanisius. Yogyakarta.

Amrullah, I. K. 2003. Nutrisi Ayam Broiler. Penerbit Satu Gunung Budi, Bogor.

Anggorodi, R. 1994. Ilmu Makanan Ternak Dasar. Gramedia Pustaka Utama. Jakarta.

Cahyono, B. 2001. Budidaya Ikan Di Perairan Umum. Kanisius. Yogyakarta. hal. 36-44.

Ikram-ul-haq, M. M. Javed, T. S. Khan and Z. Siddiq. 2005. Cotton Saccharifying Activity of Cellulases Produced by Co-culture of Aspergillus niger and Trichoderma viride. Res. J. Agric \& Biol. Sci. 1(3):241-245.

Kusriningrum. 2008. Perancangan Percobaan. Airlangga University Press. Surabaya.

Lee, S. M. and Y. M. Koo, 2001. Pilot-scale production of cellulose using Trichoderma reesei Rut C-30 in fed-batch mode, J. Microbiol. Biotechnol, 11: 229-233. 
Mustahib. 2011. Enzim. http://biologi. blogsome.com/2011/08/16/enzim/. Diakses. 16 Agustus 2012.

Nainggolan, O dan C. Adimunca. 2005. Diet Sehat Dengan Serat. Cermin Dunia Kedokteran No. 147:43-46.

NRC. 1993. Nutrient Requirements Of Fish. National Academy Press Washington, D.C.

Poedjiadi, A. 1994. Dasar-Dasar Biokimia. UI Pers. Jakarta.

Poedjiadi, A. dan F. M. T. Supriyanti. 2009. Dasar-Dasar Biokimia. Universitas Indonesia. Jakarta.

Suparjo. 2010. Analisis Bahan Pakan Secara Kimiawi: Analisis Proksimat dan Analisis Serat. Laboratorium Makanan Ternak. Fakultas Peternakan. Universitas Jambi. hal. 7.

Tillman, A.D., Reksohadiprodjo, S. Prawirokusumo, S. Lebdosoekodjo dan S. H. Hartadi 1991. Ilmu Makanan Ternak Dasar. Gadjah Mada University Press. Fakultas Peternakan UGM. Yogyakarta. 